\title{
National Forest Ecosystem Inventory System of China: Methodology and Applications
}

\author{
Bing Wang ${ }^{1,2,3, *}$, Xiang Niu ${ }^{1,2,3}$ and Wenjun Wei ${ }^{1}$ \\ 1 Institute of Forest Ecology, Environment and Protection, Chinese Academy of Forestry, Beijing 100091, China; \\ niuxiang@caf.ac.cn (X.N.); wwj0318@126.com (W.W.) \\ 2 Key Laboratory of Forest Ecology and Environment of National Forestry and Grassland Administration, \\ Beijing 100091, China \\ 3 Dagangshan National Key Field Observation and Research Station for Forest Ecosystem, \\ Xinyu 338033, China \\ * Correspondence: wangbingcfern@163.com; Tel.: +86-10-62889557
}

Received: 29 May 2020; Accepted: 2 July 2020; Published: 4 July 2020

\begin{abstract}
The technical framework of China's Forest Ecosystem Inventory System (CFEIS) was recently developed based on ecological indicators assessed continuously in the field at forest ecosystem research stations and China's Forest Resource Inventory (CNFRI) conducted every 5 years. The CFEIS consists of Field Observations (FOs)of ecological indicators and Distributed Valuations (DVs)of forest ecosystem services. The CFEIS can be used with the CNFRI to observe and monitor the ecological status of forests in China. This paper provides a brief review of the CFEIS by introducing its establishment and summarizing its application coupled with the CNFRI. For the FOs, the principles of the monitoring system layout are provided. The Chinese Forest Ecosystem Research Network (CFERN) was set up, which was the largest nationwide network of forest ecological stations in the world. The facilities and equipment were systematically assembled. The national forestry standards were drawn up for describing and measuring the ecological indicators of forest ecosystems, and these standards were used to specify data collection and transmission. For DVs, a distributed measurement method was created, and an indicator system of evaluation was studied and established, with the CNFRI integrated; a series of evaluation formulas and a package of models were also integrated with the DVs. The CFEIS integrated with the CNFRI estimates forest ecosystem services in China and the ecological benefits derived from the Grain for Green program, and a green national economic accounting system will provide an important case for monitoring and inventorying forest ecosystems at a national scale. The CFEIS can provide important experiences for forest ecosystem inventory systems in China and many other parts of the world.
\end{abstract}

Keywords: forest resource inventory; ecological stations; distributed valuation; indicator system; ecosystem services

\section{Introduction}

Forests are the most important terrestrial ecosystem on Earth and play critical roles in soil and water conservation, carbon sequestration and oxygen release, biodiversity conservation, recreation, nutrient accumulation, air filtration, and commodity production [1-3]. However, quantifying and valuing these ecosystem services remains challenging due to the spatial complexity of forest structure, its ecological processes and functions, and its temporal dynamics as driven by natural succession and land use changes [4-9]. A logical approach is to take advantage of Forest Resource Inventories (FRIs), typically produced every 5-20 years in many countries to record spatial variations and temporal changes in forests [10-12]. Early FRIs date back to the last century and are generally focused on 
timber resources [11,13]; they have since evolved to include forest health and ecological status in more modern inventories [14-16]. Satellite images are now also used [17,18]; however, they are not preferred because of their low spatial resolution. In comparison with the early FRIs based on large scale aerial photography and ground (permanent) plot calibration, more recent ones based on high spatial resolution aerial imagery and LiDAR data $[11,19,20]$ can offer greater detail and accuracy concerning forest attributes [16,21-23].

A key task in any forest ecosystem assessment is the development of key ecological indicators for different forest types, with new indicators included over time to reflect environmental concerns. In early ecological function analyses [6,24-26], indicator values were estimated from measurements carried out by researchers who used different methods at different times and locations. Although this static assessment approach is still in use today [23], it is inadequate for reflecting the spatial and temporal differences of ecosystem services and their value, which instead require a better understanding of the relationships among ecosystem structures, processes, functions and services and an assessment of indicator values on a continuous basis across ecological monitoring stations $[27,28]$.

In this paper, we introduce the technical framework of the China Forest Ecosystem Inventory System (CFEIS) developed by the Project Group for the Assessment of Forest Ecological Services in China (2010) with the support of the State Forestry Administration of China [29]. This system consists of field observations of ecological indicators from forest ecosystem research stations as well as the China Forest Resource Inventory (CNFRI), for assessing the status of forest ecosystems on a continuous basis to meet the various needs of ecological inventories and green income accounting (Figure 1) [30,31]. It can provide a quantitative scientific basis for ecological protection and ecological compensation, and can provide basic data for ecological asset accounting.

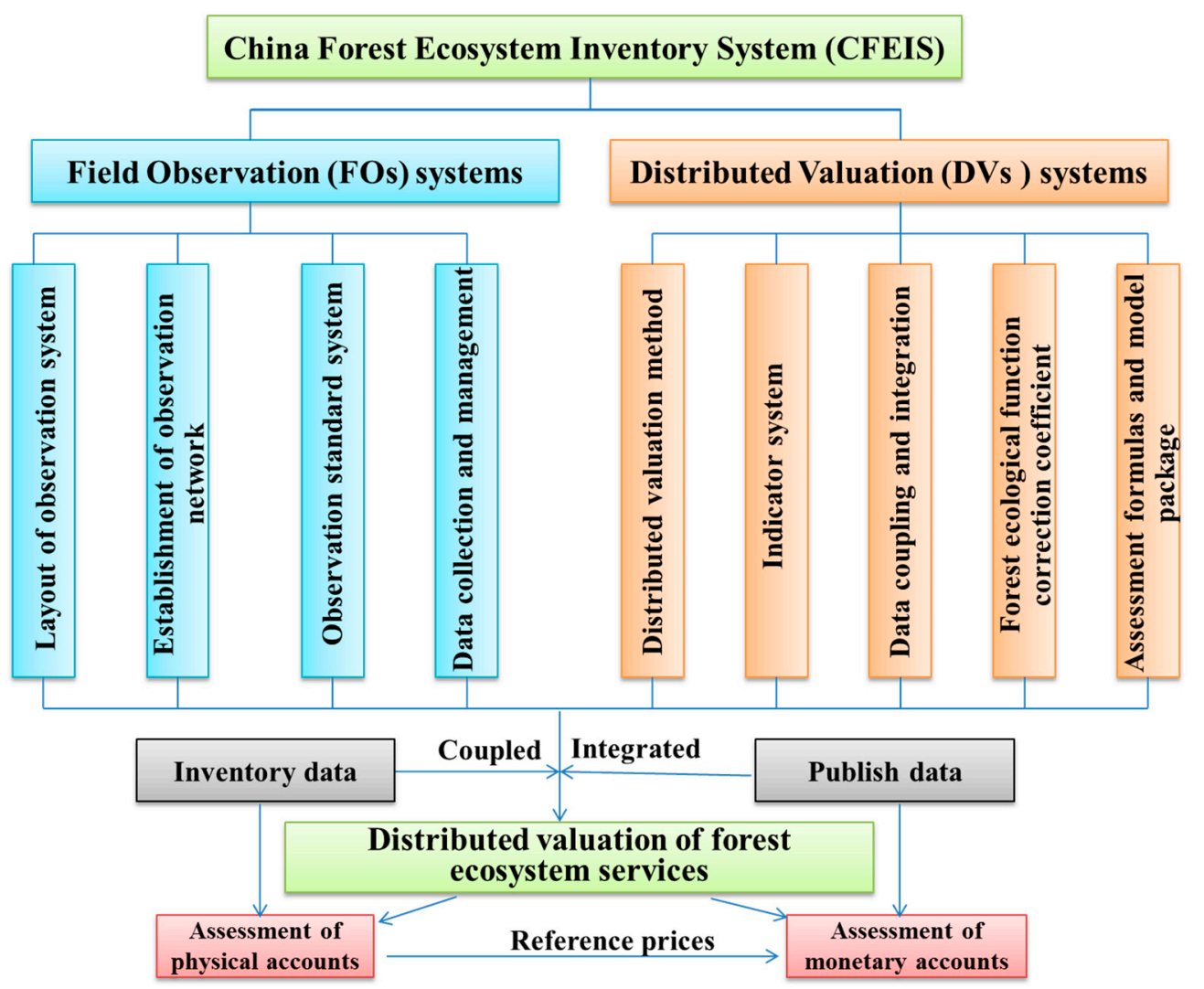

Figure 1. China Forest Ecosystem Inventory System (CFEIS) framework of Field Observation (FO) systems and Distributed Valuation (DV) systems showing data sources and coupling and integration of systems. 


\section{Current Forest Ecosystem Inventories in the World and China}

The FRIs of developed countries have evolved through three stages: timber resource investigations, forest multi-resource surveys and forest environmental monitoring (Table 1) [11,13,15,21,32,33]. This progress has been made as global environmental changes have occurred.

Table 1. International forest ecosystem inventories compared with China's.

\begin{tabular}{|c|c|c|c|c|}
\hline Nations & $\begin{array}{l}\text { Starting } \\
\text { Year }\end{array}$ & Aims for Inventory & Inventory Items & References \\
\hline \multirow{2}{*}{ Switzerland } & 1983 & Timber resource investigations & Change in forest resources & Herold and Ulmer, \\
\hline & 1993 & $\begin{array}{c}\text { Forest environmental } \\
\text { monitoring }\end{array}$ & $\begin{array}{c}\text { Forest environmental } \\
\text { conditions }\end{array}$ & $2001[32]$ \\
\hline \multirow{2}{*}{ Finland } & 1927 & Timber resource investigations & Change in forest resources & Tomppo et al. 2008 \\
\hline & 1964 & Multi-resource surveys & Integrated resources & [13] \\
\hline \multirow{3}{*}{ Sweden } & 1923 & Timber resource investigations & Change in forest resources & \\
\hline & 1983 & $\begin{array}{c}\text { Forest environmental } \\
\text { monitoring }\end{array}$ & $\begin{array}{c}\text { Forest environmental } \\
\text { conditions }\end{array}$ & $\begin{array}{c}\text { Ranneby et al. } 1987 \\
\text { [33] }\end{array}$ \\
\hline & 1993 & Multi-resource surveys & Integrated resources & \\
\hline \multirow{2}{*}{ United States } & 1928 & Forest Inventory and Analysis & Change in forest resources & $\begin{array}{l}\text { Riemann et al. } 2010 \\
\text { [11] }\end{array}$ \\
\hline & 1990 & Forest Health Monitoring & Integrated resources & Klos et al. 2009 [21] \\
\hline Germany & 1986 & Multi-resource surveys & Integrated resources & $\begin{array}{l}\text { Paivinen et al. } 1994 \\
\text { [15] }\end{array}$ \\
\hline \multirow{2}{*}{ China } & 1973 & Timber resource investigations & Change in forest resources & \\
\hline & 2009 & $\begin{array}{c}\text { Forest environmental } \\
\text { monitoring }\end{array}$ & $\begin{array}{c}\text { Forest environmental } \\
\text { conditions }\end{array}$ & \\
\hline
\end{tabular}

Germany began its FRI in 1986 after conducting national forest health surveys annually for 3 years. In 1987, they began conducting national soil surveys every 15 years, with the specific goal of identifying the causes of acid rain [15].

The United States forest inventory and analysis (FIA) started in 1928 [11,34]. Until the 1970s, this system primarily investigated forest area and growing stock; however, in 1989, the United States established a forest health monitoring (FHM) system [16,21]. At this time, multi-resource inventories and FHM were conducted simultaneously. By 1998, the United States Congress designed an integrated FIA and FHM system, known as the Forest Inventory and Monitoring (FIM) system, which represented a major turning point in the United States' use of the FRI. After a 5-year period of transition and adjustment, the United States fully adopted the new design in 2003, while simultaneously implementing the inventory and monitoring of forest resources and forest health [35]. The United States FRI was conducted by six forest experimental stations (now called "research stations") that belonged to the United States Forest Service; these are now part of the United States Long-Term Ecological Research Network.

The FRIs of Sweden and Finland were developed at the same time (and in cooperation) at the beginning of the 20th century. The growing interest in forests and the demand for timber were major driving forces for this national-level monitoring. In Finland, the first inventory was conducted from 1921 to 1924, and that in Sweden, from 1923 to 1929 [13]. Since then, these inventories have proceeded annually, continuously. In Finland, the 10th FRI (FRI10) began in 2004, while in Sweden, annual surveys have covered the entire country since 1953 [13]. In Sweden, the maintenance of biodiversity was also one of the objectives of the FRIs from 1993 onward [14].

The FRI in China (CNFRI) was initiated in 1973. The initial interests were the total forest area and timber stocking for the purposes of forest policy development and forest resource management. The technical regulations of the inventory were amended in 1999 to include "disaster type" and "disaster grade" features [36] and again in 2004 to include the "status and dynamics of forest ecosystems" and "evaluation of forest resources and ecological status" [37]. The revised provisions have since added community structure, vertical structure, species composition and origin, and vegetation coverage 
as key indicators of forest ecological status, along with providing standards for classifying these ecological indicators.

The eighth CNFRI (2009-2013) was significant for the development of forest policy and forest management in China: it adopted a complete assessment of ecological indicators and improved the FRI's technical methods and standards, while also updating the historical inventories with a valuation of forest ecosystem services [38]. It is expected that this CNFRI will continue to evolve as forest ecosystem service assessments are refined in response to increasing environmental needs and advances in science and technology.

By comparison, the FRIs of most countries in the world are characterized by monitoring an increasingly diverse list of targets. Most have experienced or are undergoing a transformation from single-target monitoring and multi-target monitoring to more comprehensive monitoring of their forests.

\section{Framework and Methodology of CFEIS}

The CFEIS includes two subsystems, field observations of ecological indicators (FOs) and distributed valuation of forest ecosystem services (DVs). The aims of the CFEIS are mainly reflected in these two sub-systems (Figure 1).

\subsection{Field Observations (FOs) of Ecological Indicators}

The FOs are carried out by staff at forest ecosystem research stations (eco-stations) situated throughout the forest ecosystem classification network, according to eco-geographical regionalization and forest site classification in China, which ensures at least one ecostation within each forest eco-unit. Emphasis is also placed on key ecological areas, biodiversity hotspots and key ecoregions so that each eco-station represents a distinct combination of forest type, landform, climate, and ecosystem process and function [39]. Currently, 85 ecostations have been established, with 10 more under construction. An additional 108 stations have been proposed to cover all the eco-units. Together, these eco-stations form the Chinese Forest Ecosystem Research Network (CFERN), the largest national forest ecosystem research network of the highest standards in the world [22].

The CFEIS' site construction, observation index system, data acquisition and transmission system all were regulated by the same requirements (Table 2 and Figure 2).

The management of the eco-stations' data envisions taking full advantage of cloud computing, the internet, meta data, mobile internet and other new data technologies to improve data accessibility and the quality of these eco-data (Figure 1) [40].

Table 2. Standard system classification used for the CFEIS.

\begin{tabular}{cl}
\hline Standard System Classification & \multicolumn{1}{c}{ Standard Usage } \\
\hline Site construction & Determine infrastructure, observation facilities, instruments and \\
Observation index & equipment, etc. \\
Observation method & Establish observation index system \\
& Clarify observation method for observation index \\
Data management & Digital construction for equipment for data transmission, data \\
& processing and analysis \\
& Data management, data quality management, data security \\
& management, etc. \\
Data applications & Establish assessment system, package of evaluation formula and model \\
\hline
\end{tabular}




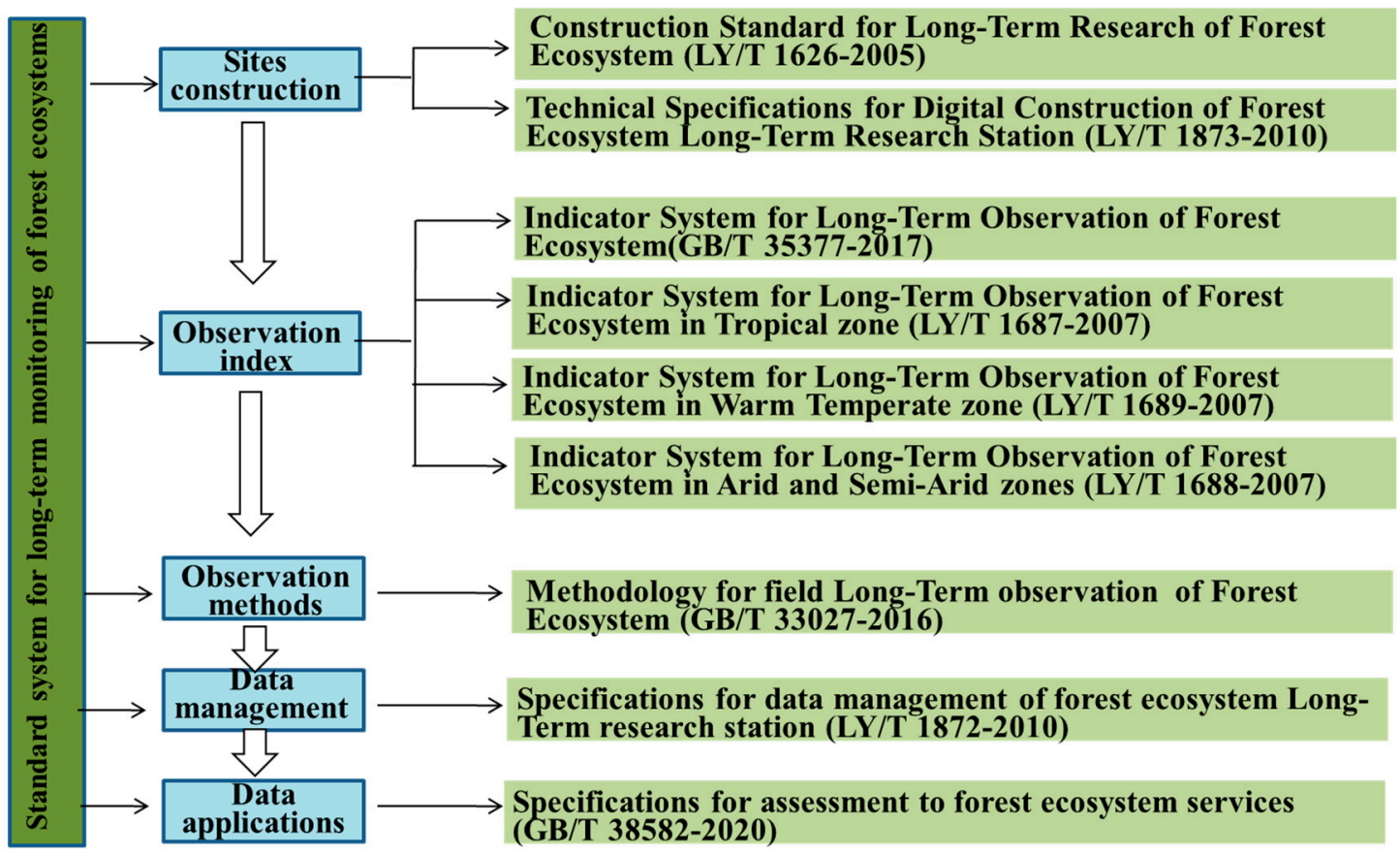

Figure 2. Standard system structure used for Long-Term monitoring of forest ecosystems as part of the CFEIS.

\subsection{Distributed Valuation (DVs) of Forest Ecosystem Services}

The economic valuation of forest ecosystem services based on calculations using FRIs and eco-station, social and economic data (Figure 3 ) involves dealing with complex and large datasets from different sources. This requires the use of a distributed valuation approach at different scales: first, by provincial administration (except in Hong Kong, Macao and Taiwan), and then, by forest type, origin (natural or plantation) and stand age (e.g., categories of young, middle-aged, pre-mature, mature and over-mature forest) (Figure 4). Formulas and reference prices are used for fourteen assessment indicators across eight categories of forest ecosystem services: water conservation, soil conservation, carbon sequestration and oxygen release, nutrient accumulation, atmospheric environment purification, forest protection, biodiversity conservation and forest recreation (Table 2 and Figure 5).

Three data sources including the forest resource inventory, eco-station and public resources were coupled and integrated to develop the DV (Figure 6). The forest resource inventory data contain the forest areas and growing stock, and harvested volume, while the public resources data released via government statistics and prices include social expenses such as water purification costs, sewage charges, etc. The data collected by the eco-stations from representative forest sites are adjusted by 600 secondary observation points and 10,000 long-term permanent plots $(30 \mathrm{~m} \times 30 \mathrm{~m})$ via forest ecological correction coefficients [41], to better reflect forest variations produced by different dominant trees, species origins, stand ages and site conditions. Calculations for relatively homogeneous stand polygons (from $<1$ ha to $>1000$ ha in size) are aggregated to scale up to different levels by using statistical sampling principles, remote sensing inversions and model simulations (IBIS, Integrated Biosphere Simulator) [42].

When forest ecosystem service quality is transformed into value quantity, it should conform to the principles of "equivalent substitution " and "weight equivalent balance". Not only economics and commodity market theory but also ecosystem service principles and processes should be considered. By rebalancing many reasonable price parameters, the proportion of services between different forest types in different areas was made consistent with the actual situation of forests. 


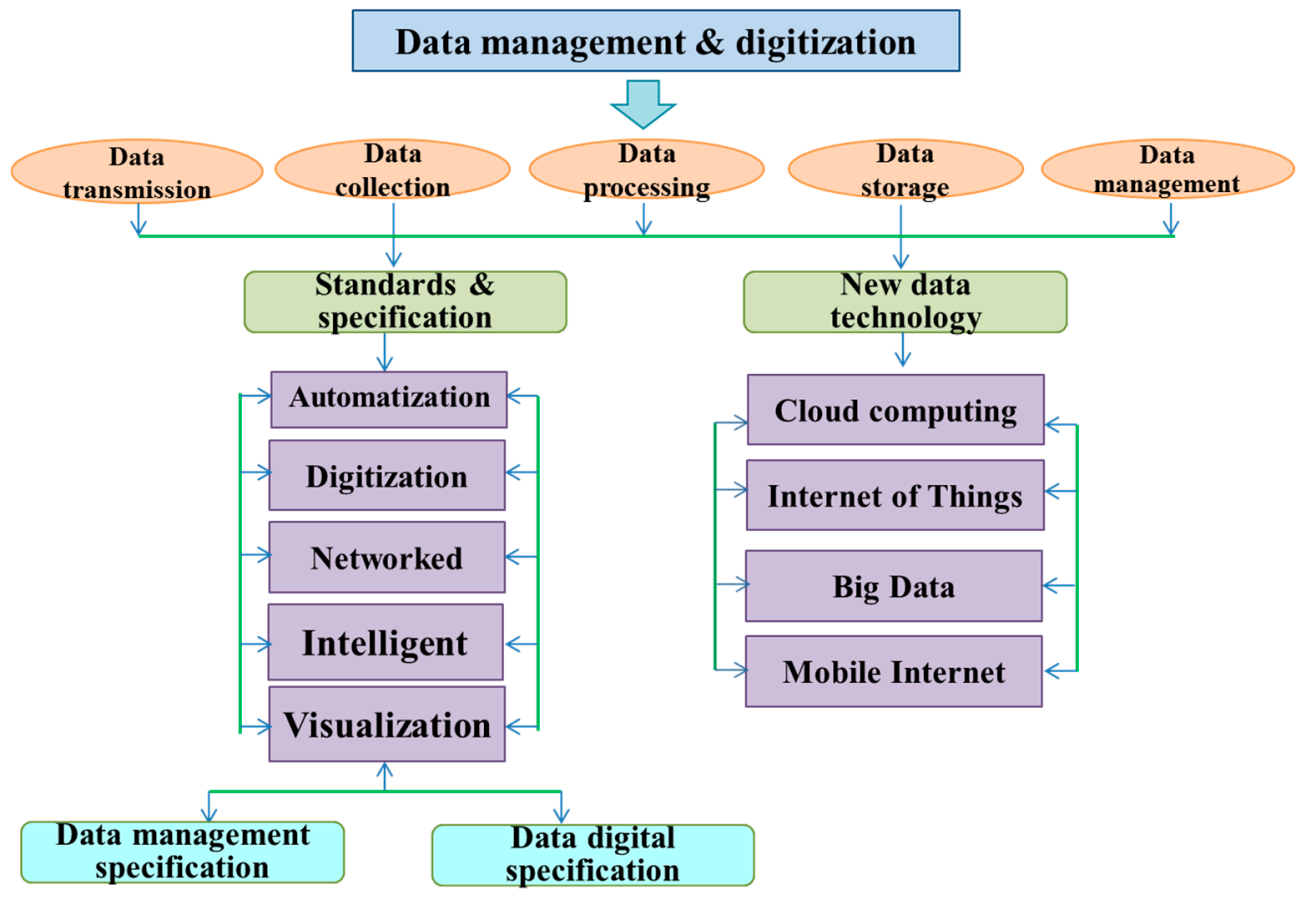

Figure 3. Management of the eco-stations' data from the Chinese Forest Ecosystem Research Network (CFERN) used for the CFEIS.

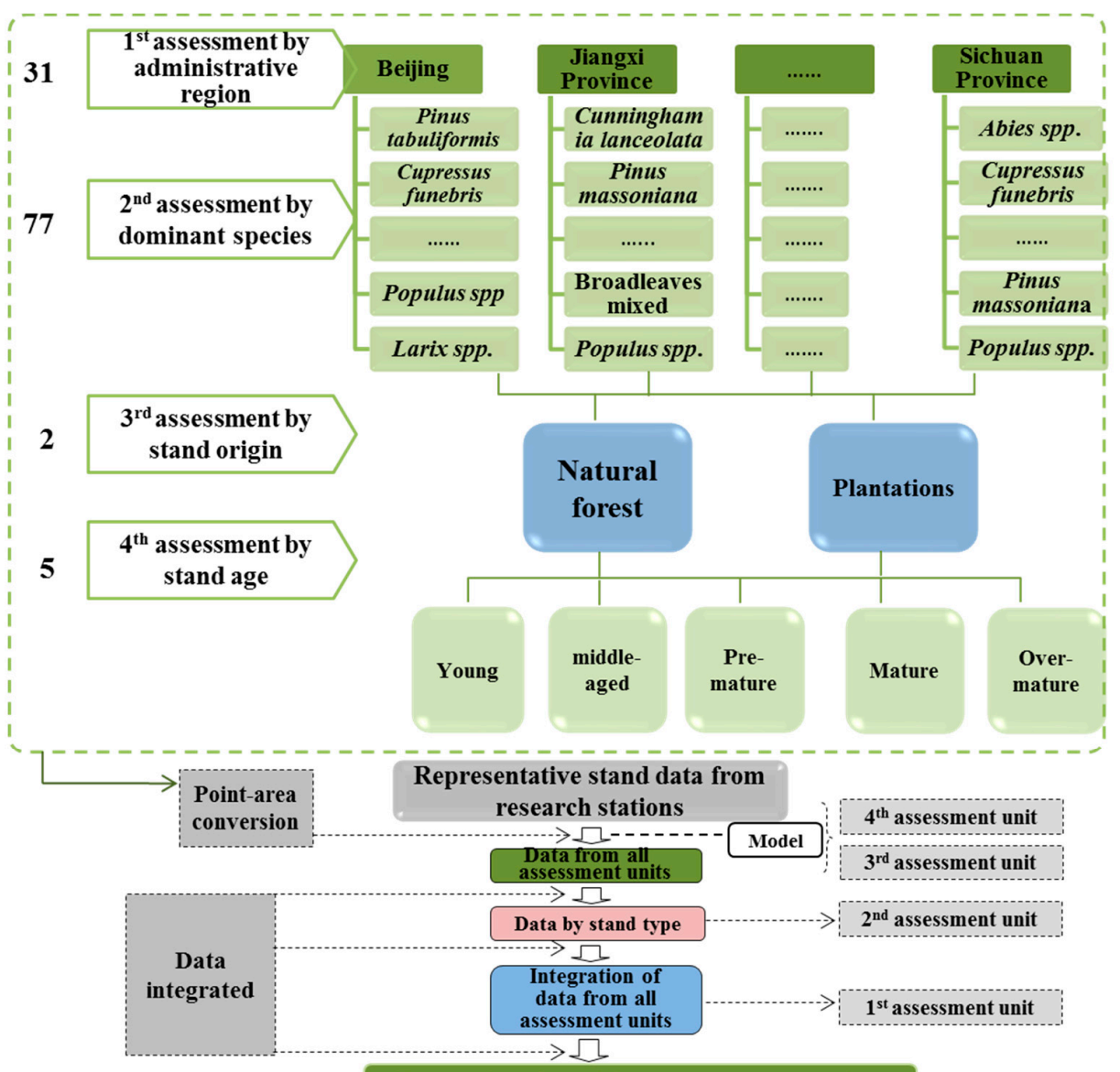

Economic value of forest ecosystem services

Figure 4. Description of how the Distributed Valuations (DVs) for forest ecosystems services in China are determined using various data sources. Note: “... " in the Figure denotes the other provinces and tree species in China. 


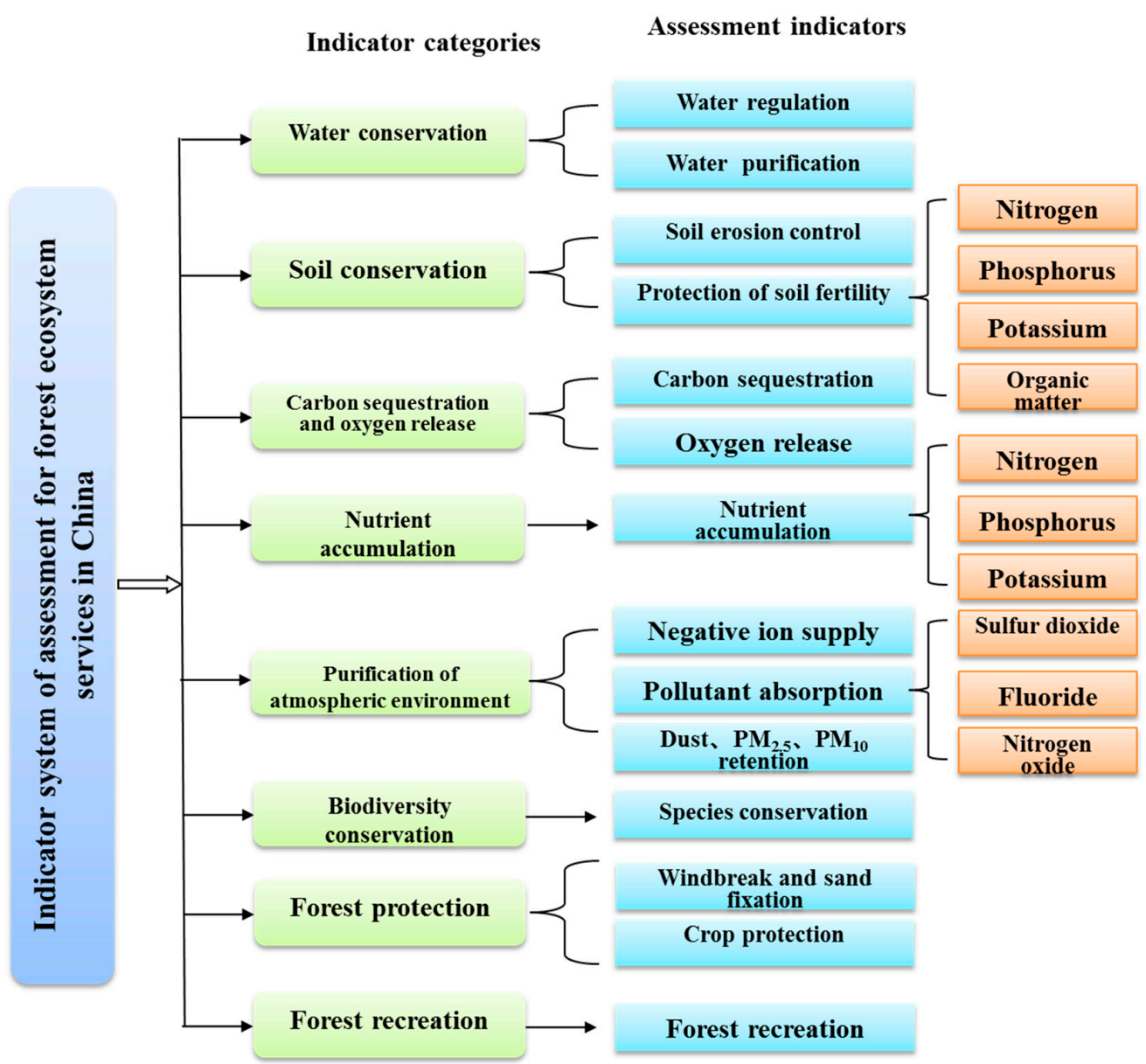

Figure 5. Indicator system used for assessing forest ecosystem services in China.

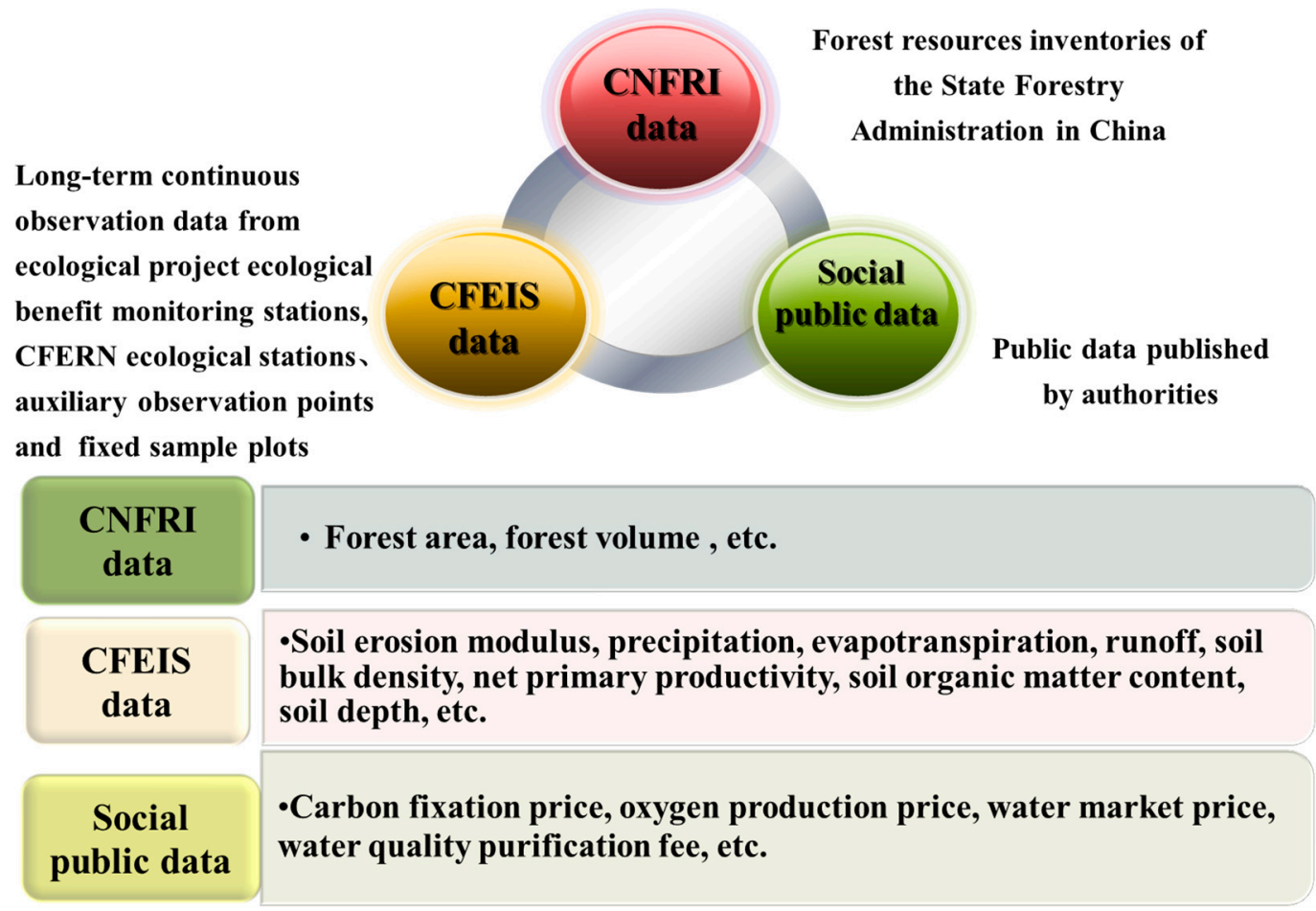

Figure 6. Data sources and integration in CFEIS. 


\section{Applications and Practices for CFEIS in China}

The CFEIS is a complicated system that has taken many years to develop. The system has been successfully applied to the seventh and eighth FRIs for the valuation of national forest ecosystem services, the ecological benefit assessment in the Grain for Green program and Natural Forest Protection Project in China, and Green GDP Accounting (Table 3) [29,43-45]. However, further refinement is expected as society's needs change and science and technology advance. Outputs from this research will help to fine-tune CFEIS' technology to meet various needs for monitoring and valuating forests in terms of their ecosystem services and ecological conditions and benefits.

Table 3. Assessment of forest ecosystem services based on the CFEIS.

\begin{tabular}{|c|c|c|c|}
\hline Assessment Area & $\begin{array}{l}\text { Assessment } \\
\text { Period }\end{array}$ & $\begin{array}{l}\text { Total Value of Forest } \\
\text { Ecosystem Service } \\
\text { (Trillion CNY/Year) }\end{array}$ & References \\
\hline \multicolumn{4}{|l|}{ National scale } \\
\hline China & 2004-2008 & 10.01 & $\begin{array}{l}\text { Project Group of Assessment of Forest } \\
\text { Ecological Services in China }(2010,2018)\end{array}$ \\
\hline China & 2009-2013 & 12.68 & $\begin{array}{l}\text { Project Group of Assessment of Forest } \\
\text { Ecological Services in China (2018) }\end{array}$ \\
\hline \multicolumn{4}{|l|}{ Ecological project scale } \\
\hline Grain for Green projects ${ }^{a}$ & 2014 & 1.00 & $\begin{array}{l}\text { CSFA (State Forestry Administration of } \\
\text { China) } 2015 \text { (China 2015) }\end{array}$ \\
\hline Grain for Green projects ${ }^{b}$ & 2015 & 0.13 & CSFA 2016a (China 2016a) \\
\hline $\begin{array}{c}\text { Natural Forest Protection } \\
\text { Project }^{c} \\
\text { Provincial scale }\end{array}$ & 2016 & 0.64 & CSFA 2016b (China 2016b) \\
\hline Heilongjiang & 2015 & 1.76 & Yang et al. 2016 (Yanget al. 2016) \\
\hline Jilin & 2014 & 0.84 & Ren et al. 2016 (Renet al. 2016) \\
\hline Anhui & 2013 & 0.48 & Xia et al. 2016 (Xiaet al. 2016) \\
\hline
\end{tabular}

Note: Superscript letters in the table denote the following areas. ${ }^{a}$ middle and upper reaches of the Yangtze River and Yellow River; ${ }^{b}$ northern desertification area; ${ }^{c}$ northeast and Inner Mongolia key state-owned forest region.

In so doing, for the first time, we may continuously chronicle the service value of forest ecosystems at the national level, so that their association with human wellbeing may be visualized via data mining, which should improve China's national economic accounting system and the preparation of its natural resources balance sheet.

In addition, the CFEIS has already been used to evaluate the ecosystem services of forest ecosystems in various provinces, such as those of Heilongjiang, Jilin and Anhui province (Table 3) [27,46,47]. These assessment results are important for proper forestry management and policy planning. The application of the CFEIS will promote a better understanding of the formation and regulation of the mechanisms governing forest ecosystem services at a regional scale, systematic analysis of the characteristics of different ecological services in different regions, and also provide important technical support for China's green national economic accounting.

\section{Implications for Other Countries}

Compared to the relative independence of ecological research and economic accounting in research frameworks for domestic and foreign systems for forest ecosystem services, the CFEIS is an example of a comprehensive system that integrates field observations, evaluation measurements, forest resources and social public data [39,41]. The FOs supply the big data, while the DVs not only guarantee an accurate assessment of ecosystem services but also solve the problem of transformation across different temporal and spatial scales [41]. The corresponding standards are unified from the layout and construction of the observation facilities-through data collection, transmission and storage-to the selection and calculation of the ecosystem services evaluation indexes. 
The CFEIS can provide a representation of the characteristics of each forest ecosystem assessment region by using a reasonable station layout and via a standardized system to regulate the various phases of observation, analysis, measurement evaluation, etc. [41]. The long-term study of forest ecosystems has broken the previous research focus upon a single index or a category index. It provides a scientific basis for investigating the structures, processes and functions of forest ecosystems. This presents a great step forward in evaluation indexes for forest ecosystem service functions toward standardization, dynamism and scientificness. A discontinuity and independence evaluation index selection method for the CFEIS was proposed - with which systematic, procedural and nodal considerations are afforded more attention; eventually eight categories of fourteen evaluation indexes were selected $[39,41]$. To make the assessment more scientific and credible when evaluating biodiversity conservation, the evaluation model was modified by introducing the age of the ancient tree index, the endemic species index and the endangered index to objectively reflect the special value of specific species in a particular environment [48]. The DV uses four levels of calculation units, and divides the smallest unit into the stand age, and it therefore fully considers both regional and forest type characteristics to improve the value of ecosystem services [41].

China has constructed the largest nationwide network of forest ecological stations and systematically assembled the needed facilities and equipment [49]; as such, the indices described here are measurable using national forestry standards every 1-5 years, and data acquisition and transmission are possible. In the process of building the DV system, a distributed measurement method was created: an index system of evaluation was examined and established, and datasets of national forest resources and related statistics were integrated. This is in addition to proposing a system of correction coefficients for forest ecological functions that could be integrated by a series of evaluation formulas and a package of models. The CFEIS can be used along with the national forest resource inventory to function as one of the key technologies for observing and evaluating forest ecological conditions. This includes an inventory of national forest ecosystem services, estimates of the ecological benefits derived from returning farmland to forests and a green national economic accounting system.

\section{Potential Questions}

China's forests are large, and the diversity of its forest ecosystems is very complex. The scientific evaluation of ecosystem services on a large scale is still exploratory and forward-looking work: it will take time to develop a comprehensive and in-depth study of multiple subjects, but breakthroughs in theory and practice have occurred and will occur. To further advance this work, the following aspects should be strengthened. Firstly, relying on the forest ecological stations, carrying out comprehensive observations for a system of ecosystem positions, basic research activity, using large data-set theory and closely integrating the "Internet of things" to realize automation and real-time performance in forest monitoring should be considered. Secondly, there were many challenges overcome to accurately assess ecosystem services, quantifying the secondary effects of Air Pollution Removal (i.e., effects of Biogenic Volatile Organic Compound (BVOC) emissions on secondary pollutant formation and ozone concentrations). BVOCs could be one of the most important drivers of the formation and growth of Secondary Organic Aerosols (SOA). In the forest area, under the environmental conditions without Anthropogenic Volatile Organic Compounds (AVOCs) in the atmosphere, the isoprene released by plants will cause the regional atmosphere to produce a certain concentration of ozone. Thirdly, there are many challenges when integrating ecosystem services in national accounting; avoidance of possible double counting was necessary when assessing the value of ecosystem assets. The protective functions of shelterbelts-such as water storage, wind prevention, and soil and fertilizer preservation-can improve crop yield as well. Forest landscape, air purification, oxygen release and other recreational functions can create forest park entrance income. Most of the measurements directly incorporate this part of income into the forest environment value quantity, but at the same time, they use the alternative measurement method to calculate the value of the above environmental function physical quantity separately and also record the forest environmental value quantity, which causes double calculation. 
Fourthly, the reasonable linking of ecological products and economic prices will transform potential, non-market value into real market value. This could form a universally recognized theoretical system. Fifthly, the transformation of ecosystem functions into ecosystem services should be researched, through the development a scientific understanding of the relationship between ecosystem service supply, consumption and human well-being to meet and improve human well-being. Sixthly, promoting the integration of ecosystem service value assessment into the national economic accounting system, and encouraging the implementation of "ecological GDP" and an "ecological compensation system" should be considered. Forest resources are important ecological assets supporting the development of human society; exploring the value and potential of forest ecosystem services is of great significance for the rational utilization and protection of forest resources.

\section{Conclusions}

The CFEIS coupled with the CNFRI will estimate forest ecosystem services in China and the ecological benefits derived from the Grain for Green program and establish a green national economic accounting system. This will provide an important case for monitoring and inventorying forest ecosystems on a national scale. Compared to the relative independence of ecological research and economic accounting in the research frameworks of domestic and foreign systems for forest ecosystem services, the CFEIS is an example of a comprehensive system that integrates field observations, evaluation measurements, resources and social public data. The CFEIS can provide important experiences for the development and implementation of forest ecosystem inventories in China and many other parts of the world.

Author Contributions: B.W. conceived and designed the study. X.N. analyzed the data. W.W. wrote the paper. All authors have read and agreed to the published version of the manuscript.

Funding: This study was funded by the Central Non-profit Research Institution of CAF (CAFYBB2020ZD002-2 and CAFYBB2020ZE003). Financial support was also provided by CFERN \& BEIJING TECHNO SOLUTIONS through Award Funds based on excellent academic achievements.

Conflicts of Interest: The authors declare no conflict of interest.

\section{References}

1. Adger, N.; Brown, K.; Cervigni, R.; Moran, D. Total economic value of forests in Mexico. Ambio 1995, 24, 286-296.

2. Mäler, K.G.; Aniyar, S.; Jansson, A. Accounting for ecosystem services as a way to understand the requirements for sustainable development. Proc. Natl. Acad. Sci. USA 2008, 105, 9501-9506. [CrossRef] [PubMed]

3. Zhao, T.Q.; Ouyang, Z.Y.; Zheng, H.; Wang, X.K.; Miao, H. Forest ecosystem services and their valuation in china. J. Nat. Resour. 2004, 4, 480-491.

4. Bagstad, K.J.; Johnson, G.W.; Voigt, B.; Villa, F. Spatial dynamics of ecosystem service flows: A comprehensive approach to quantifying actual services. Ecosyst. Serv. 2013, 4, 117-125. [CrossRef]

5. Bennett, E.M.; Peterson, G.D.; Gordon, L.J. Understanding relationships among multiple ecosystem services. Ecol. Lett. 2009, 12, 1394-1404. [CrossRef]

6. Costanza, R.; D’arge, R.; De Groot, R.S.; Farber, S.; Grasso, M.; Hannon, B.; Limburg, K.; Naeem, S.; O'neill, R.V.; Paruelo, J.; et al. The value of the world's ecosystem services and natural capital. Nature 1997, 387, 253-260. [CrossRef]

7. Daily, G.C. Nature's Services: Societal Dependence on Natural Ecosystems; Island Press: Washington, DC, USA, 1997.

8. Seppelt, R.; Dormann, C.F.; Eppink, F.V.; Lautenbach, S.; Schmidt, S. A quantitative review of ecosystem service studies: Approaches, shortcomings and the road ahead. J. Appl. Ecol. 2011, 48, 630-636. [CrossRef]

9. Yang, J.; Dai, G.; Wang, S. China's national monitoring program on ecological functions of forests: An analysis of the protocol and initial results. Forests 2015, 6, 809-826. [CrossRef]

10. Kleinn, C.; Dees, M.; Polley, H. Forest Inventory and Survey Systems in Germany; Federal Ministry of Food, Agriculture and Forestry: Bonn, Germany, 1998. 
11. Riemann, R.; Wilson, B.T.; Lister, A.; Parks, S. An effective assessment protocol for continuous geospatial datasets of forest characteristics using USFS Forest Inventory and Analysis (FIA) data. Remote Sens. Environ. 2010, 114, 2337-2352. [CrossRef]

12. Shaw, C.H.; Hilger, A.B.; Metsaranta, J.; Kurz, W.A.; Russo, G.; Eichel, F.; Stinsonb, G.; Smyth, C.; Filiatrault, M. Evaluation of simulated estimates of forest ecosystem carbon stocks using ground plot data from Canada's national forest inventory. Ecol. Model. 2014, 272, 323-347. [CrossRef]

13. Tomppo, E.; Olsson, H.; Stahl, G.; Nilsson, M.; Hagner, O.; Katila, M. Combining national forest inventory field plots and remote sensing data for forest databases. Remote Sens. Environ. 2008, 112, 1982-1999. [CrossRef]

14. Bachmann, P.; Köhl, M.; Päivinen, R. Assessment of Biodiversity for Improved Forest Planning; Springer Science \& Business Media: Dordrecht, The Netherlands, 2013.

15. Paivinen, R.; Lund, H.G.; Poso, S.; Zawila-Niedzwiecki, T. IUFRO International Guidelines for Forest Monitoring: A Project of IUFRO Working Party S4; IUFRO: Vienna, Austria, 1994.

16. Woodall, C.W.; Amacher, M.C.; Bechtold, W.A.; Coulston, J.W.; Jovan, S.; Perry, C.H.; Randolph, K.C.; Schulz, B.K.; Smith, G.C.; Tkacz, B.; et al. Status and future of the forest health indicators program of the USA. Environ. Monit. Assess. 2011, 177, 419-436. [CrossRef]

17. He, H.; Pan, Y.Z.; Zhu, W.Q.; Liu, X.L.; Zhang, Q.; Zhu, X.F. Measurement of terrestrial ecosystem services value in China. Chin. J. Appl. Ecol. 2005, 16, 1122-1127.

18. Ouyang, Z.Y.; Zheng, H.; Xiao, Y.; Polasky, S.; Liu, J.; Xu, W.; Wang, Q.; Zhang, L.; Xiao, Y.; Rao, E.; et al. Improvements in ecosystem services from investments in natural capital. Science 2016, 352, 1455-1459. [CrossRef] [PubMed]

19. King, D.J. Airborne remote sensing in forestry: Sensors, analysis and applications. For. Chron. 2000, 76, 859-876. [CrossRef]

20. Woods, M.; Pitt, D.; Penner, M.; Lim, K.; Nesbitt, D.; Etheridge, D.; Treitz, P. Operational implementation of a LiDAR inventory in Boreal Ontario. For. Chron. 2011, 87, 512-528. [CrossRef]

21. Klos, R.J.; Wang, G.G.; Bauerle, W.L.; Rieck, J.R. Drought impact on forest growth and mortality in the southeast USA: An analysis using forest health and monitoring data. Ecol. Appl. 2009, 19, 699-708. [CrossRef]

22. Niu, X.; Wang, B.; Liu, S.R.; Liu, C.J.; Wei, W.J.; Kauppi, P.E. Economical assessment of forest ecosystem services in China: Characteristics and implications. Ecol. Complex. 2012, 11, 1-11. [CrossRef]

23. Xie, G.; Li, W.; Xiao, Y.; Zhang, B.; Lu, C.; An, K.; Wang, J.; Xu, K.; Wang, J. Forest Ecosystem Services and Their Values in Beijing. Chin. Geogr. Sci. 2010, 20, 51-58. [CrossRef]

24. Anielski, M.; Wilson, S. Counting Canada's Natural Capital: Assessing the Real Value of Canada's Boreal Ecosystems; Canadian Boreal Initiative; Pembina Institute: Ottawa, ON, Canada, 2005.

25. Merlo, M.; Croitoru, L. Valuing Mediterranean Forests: Towards Total Economic Value; CABI Publishing: Wallingford, UK, 2005.

26. Ouyang, Z.Y.; Wang, X.K.; Miao, H. A primary study on Chinese terrestrial ecosystem services and their ecological-economic values. Acta Phys. Sin. 1999, 19, 607-613.

27. Yang, G.T.; Wang, B.; Ying, T.; Li, F.; Yang, S.T.; Huang, L.S.; Liu, Z.Y.; Niu, X. Study on forest Ecosystem Services and Ecosystem Services in Heilongjiang Province; China Forestry Press: Beijing, China, 2016.

28. Zhang, B.; Li, W.; Xie, G. Ecosystem services research in China: Progress and perspective. Ecol. Econ. 2010, 69, 1389-1395. [CrossRef]

29. Project Group of Assessment of Forest Ecological Services in China. Assessment of Forest Ecological Services in China; China Forestry Press: Beijing, China, 2010.

30. Krieger, D.J. The Economic Value of Forest Ecosystem Services: A Review; The Wilderness Society: Washington, DC, USA, 2001.

31. Torras, M. The total economic value of Amazonian deforestation, 1978-1993. Ecol. Econ. 2000, 33, $283-297$. [CrossRef]

32. Herold, A.; Ulmer, U. Stand stability in the Swiss National Forest Inventory: Assessment technique, reproducibility and relevance. For. Ecol. Manag. 2001, 145, 29-42. [CrossRef]

33. Ranneby, B.; Cruse, T.; Haegglund, B.; Jonasson, H.; Swaerd, J. Designing a new national forest survey for Sweden. Studia For. Suec. 1987, 177, 2-28.

34. Xiao, X.W.; Yao, C.T.; Chen, X.F.; Song, C.Q.; Zeng, W.S.; Zhang, T.P. Main points of forest resource inventory in US and guiding suggestions. For. Resour. Manag. 2005, 2, 27-42. 
35. Ye, R.H. New design of the US national forest inventory and analysis system. For. Resour. Manag. 2003, 3, 65-68.

36. Chen, X.F.; Zeng, W.S.; Xiong, Z.B.; Zhang, M. New development of China National Forest Inventory (NFI): On revision of NFI technical regulations. For. Resour. Manag. 2004, 5, 40-45.

37. State Forestry Administration of China. China National Forest Inventory Technical Regulations; State Forestry Administration of China: Beijing, China, 2004.

38. Shi, H.X.; Wang, B.; Niu, X. Analysis of Chinese forest ecosystem services characteristics based on continuous inventory system for forest ecology. J. Beijing For. Univ. 2016, 38, 42-50.

39. Niu, X.; Wang, B. Assessment of forest ecosystem services in china: A methodology. J. Food Agric. Environ. 2013, 11, 2249-2254.

40. Wang, B.; Li, S.N. Construction and techniques of the digital forest long-term ecological research station. Sci. Silvae Sin. 2006, 42, 116-121.

41. Wang, B. Construction and utilization of continuous inventory system for forest ecology. J. Beijing For. Univ. 2015, 37, 1-8.

42. Niu, X. Study on Forest Ecological Benefits Distributed Measurement and Its Quantification Compensation: Taking Guangdong and Liaoning Province as Demonstration Cases; Beijing Forestry University: Beijing, China, 2012.

43. State Forestry Administration of China (CSFA). National Report of Ecological Benefit Monitoring for the Grain for Green Project: 2014; China Forestry Press: Beijing, China, 2015.

44. CSFA. National Report of Ecological Benefit Monitoring for the Grain for Green Project: 2015; China Forestry Press: Beijing, China, 2016.

45. CSFA. National Report of Ecological Benefit Monitoring for the Natural Forest Protection Project: 2015; China Forestry Press: Beijing, China, 2016.

46. Ren, J.; Song, Q.F.; Shan, G.M.; Zhang, H.Y.; Niu, X.; Wang, B. Study on Forest Ecosystem Services and Ecosystem Services in Jilin Province; China Forestry Press: Beijing, China, 2016.

47. Xia, S.G.; Niu, X.; Song, Q.F.; Wang, X.J.; Wang, B. Study on Forest Ecosystem Services and Ecosystem Services in Anhui Province; China Forestry Press: Beijing, China, 2016.

48. Song, Q.F.; Wang, B.; Wang, J.S.; Niu, X. Endangered and endemic species increase forest conservation values of species diversity based on the Shannon-Wiener index. iForest 2016, 9, 469-474. [CrossRef]

49. Niu, X.; Wang, B.; Wei, W.J. Chinese forest ecosystem research network: A platform for observing and studying sustainable forestry. J. Food Agric. Environ. 2013, 11, 1008-1016. 